\title{
Green Procurement in Construction Industry: A Theoretical Perspective of Enablers and Barriers
}

\author{
Muhammad Waris Ali Khan ${ }^{1, *}, \mathrm{Ng}$ Hwee Ting ${ }^{1, *}$, Lee Chia Kuang ${ }^{1}$, Mohd Ridzuan Darun ${ }^{1}$, \\ U. Mehfooz ${ }^{1}$, and Mohd Faris Khamidi ${ }^{2}$ \\ ${ }^{1}$ Faculty of Industrial Management, Universiti Malaysia Pahang, 26300 Gambang, Kuantan, Malaysia \\ ${ }^{2}$ Built Environment, University of Reading Malaysia, 79200 Iskandar Puteri Johor, Malaysia
}

\begin{abstract}
The global environment is gradually deteriorating, and the construction sector is commonly considered as most influential to such issues extending from non-renewable resource depletion to global warming. Developing countries in Asia produce more than $60 \%$ of the $\mathrm{CO}_{2}$ emissions and this increases from year to year in the real estate industries. Traditional building materials experience low environmental performance; furthermore, they can lead to several risks related to the environment which consists of the construction process and building operation, such as the diverse emission of hazardous waste. Therefore, green procurement has been considered as a gateway approach for enhancing the environmental performance in the building industry. Since the procurement phase is the early stage of the project lifecycle, it is the most noteworthy to ensure a sustainable future perspective. Therefore, this paper intends to establish a theoretical outlook to exploit the enablers and barriers for promoting green procurement in the construction industry.
\end{abstract}

\section{Introduction}

According to the report of Growth Opportunities in the Global Construction Industry, the global construction industry is expected to reach an estimated $\$ 10.5$ trillion by 2023 , and it is forecasted to grow at a Compound Annual Growth Rate (CAGR) of 4.2\% from 2018 to 2023 [1]. The construction industry is an important player in the worldwide economics. Based on studies in developed countries, the construction industry has exploited $30-40 \%$ of its natural resources; $50 \%$ of the energy was used for heating and cooling in buildings, approximately $40 \%$ of the materials' worldwide consumption had been converted to the building environment and $30 \%$ of the energy was used in operational requirements [2].

\footnotetext{
* Corresponding author: waris@ump.edu.my
} 
The construction industry and sustainable development issues are intimately related with each other because this sector is a major contributor of the decrease of non-renewable resources. Sustainable development was defined by the Brundtland Report (1987) as a "development that meets the needs of the present without compromising the ability of future generations to meet their own needs" [3]. According to the sustainable development notion in the Brundtland Report, many researchers agree that construction procurement is a vital process to handle the environmental issues in the construction industry. Procurement means acquiring goods and/or services from an outside source. Other terms include purchasing and outsourcing. Procurement management is one of the key roles to determine the success or failure of a project; an overwhelming majority $(87 \%)$ believe good procurement to be synonymous with a successful project [4].

However, procurement for construction is different from other products. Ruparathna and Hewage (2015a) contended that construction procurement is the "process of acquiring goods and services to realize a constructed facility according to predefined requirements" [5]. Procurement plays significant roles in any infrastructure development because it will affect the overall project performance [6]. Procurement that concerns environmental impacts is known as green procurement. The term of 'green' in this research means recognition, integration and implementation of environmental practices or initiatives or systems designed to minimize environmental impacts during their lifecycle [7]. For a construction project, practicing green procurement means the organization should be responsible in minimizing the environmental impact from the activities throughout the project's stages.

Green procurement integrates environmental considerations with the combination of cost and quality considerations in the procurement process. Sustainability's Triple Bottom Line (TBL) consists of environmental, economic and social aspects [8]. The concept of sustainability is 'cradle to grave', which considers the full lifecycle of the project. It does not only consist of the project lifecycle but also the asset and product lifecycles that must be comprised from the conception phase until the completion and disposal [9]. The emerging green construction has a direct impact on the dynamics of the construction industry, such as reducing the carbon footprint, building information systems for efficient building management, bridging the lock-up device system with the aim to increase the life of the structure, and using fiber-reinforced polymer composites for the rehabilitation of aging structures [1]. From the past research, implementing green procurement in the construction industry is beneficial and harmless. However, it will encounter challenges when carrying it out in the construction industry. Therefore, this paper has discussed the benefits and evaluated the challenges encountered in implementing green procurement in the construction industry.

\section{Green Procurement}

The Green Council defined green procurement as the acquisition of "products or services which minimize or provide positive environmental impacts" through the factoring of "environmental concerns into major purchasing strategies, policies and directives" [10]. Green procurement integrates environmental considerations with the combination of cost and quality into the procurement process. For instance, green procurement involves the purchase of sustainable technologies, products and services for water, energy, waste and material efficiency, such as recycling, in council buildings, facilities, offices, works and fleets.

Green procurement also calls for sustainable procurement. It is the first broad concept that emerged following the Rio Earth Summit in 1992. After that summit, European countries had taken early initiatives to work on developing environmental procurement policies and procedures. Nowadays, governments from overseas and domestically have come out with policies to promote the principles of sustainable procurement. 
The aims of promoting green procurement are to reduce the adverse environmental, social and economic impacts of purchased products and services throughout their lives. Sustainable procurement looks beyond the up-front cost to make purchasing decisions based on the entire lifecycle of the products' and services' care which involves costs, environmental and social risks and benefits, and broader social and environmental consequences.

The United Kingdom Government had created a "Sustainable Procurement Task Force" which had developed a definition for sustainable procurement in 2005. The Australian Procurement and Construction Council (APCC) was given the definition that was used by the UN and the UK Government: "A process whereby organizations meet their needs for goods, services, works and utilities in a way that achieves value for money on a whole life basis in terms of generating benefits not only for the organization, but also for the society and the economy, whilst minimizing damage to the environment" [11].

\section{Enablers of implementing green procurement in the construction industry}

\subsection{Environmental Benefits}

According to the UNEP (2009), the building sector has the largest potential for significantly reducing greenhouse gas emissions compared to other major emitting sectors [12]. An environmental aspect is a way of selecting more efficient materials or products and launching support for an environmentally conscious design of principles, such as cradle-to-cradle. By implementing green procurement in the starting of a project, it is avoiding any air pollution, water pollution, or even soil pollution in the construction industry. With the green procurement knowledge, stakeholders will know how to control the chemicals and handle the hazardous substances. This notion motivates the contractor to follow environmental laws and regulations when arranging raw materials; such as, it is important that procurement is made by purchasing the timber or the timber materials from legally harvested forests. It also considers the sustainability of managing forest activities to avoid a negative impact made by human beings. It will reduce the greenhouse gas emissions to the environment due to the purchasing of green materials, such as recycled steel and glass, as well as renewable materials like rubber and bamboo. Besides that, water management also provides a benefit with saving on water usage by selecting more water efficient fittings. It also improves water quality by reducing certain releases into the water, such as the chemical pollution of watercourses. Other than that, a green building can reduce the consumption of energy to less than half of what a conventional building does, with similar reductions in potable water usage, runoff to sewer and solid waste [13]. One of the energy efficient ways is to install energy-efficient windows and doors, and by installing a commercial solar panel system which uses renewable energy to power the building.

\subsection{Social Benefits}

Green procurement is a way to enhance the quality of life [14]. Implementing green procurement significantly reduces the negative impact to the environment, which reduces or minimizes the probability of accidents, directly reducing liability and safety and health costs. For example, it will produce a healthier and more ambient operational place for the workers who are involved in green buildings, leading to fewer cases of headaches, as well as asthma and allergies. In addition, contractors can reduce or minimize the use of toxic chemicals to provide a healthier working environment. Hence, it leads an organization to eliminate the cost of reporting accidents, as well as the handling, storage and disposal requirements. Other 
than that, cleaner air and water in the environment may improve the community and worker health. Hence, high indoor air quality can enhance worker productivity. Besides that, implementing green procurement in construction projects will lead contractors to produce a higher level of quality of the project and deliver better performance to public authorities and, ultimately, the citizens. Constructing green roof systems can offer many benefits, involving rainwater management, on-site gardens and protecting the roof from the effects of harmful UV light [15]. It will provide a healthy environment and lifestyle. Besides that, maximizing natural light is a way to save energy costs for the users in the long term. Being sustainable, suppliers play a crucial role in the construction industry. They can be socially responsible by implementing ethical practices and following legislative obligations, and the actions that give benefits to the society, such as diversity, inclusiveness, integration, equality and regeneration. Lastly, green procurement is a way to promote the concept of environmental caring for human beings.

\subsection{Economic Benefits}

Implementing green procurement in construction projects has helped the contractors save money and resources during the projects' lifecycle processes. According to the CEA (2011), by implementing green building, it saves the majority of the funds in the utility costs and maintenance part [16]. It will drive contractors to choose their purchases more efficiently and use renewable raw materials and green equipment in the process. While green procurement will lead to cost avoidance, such as with lower hazardous material management and waste management fees, it will also save the time and cost of reporting and follow-up. For instance, contractors could use materials which are easier to recycle or reuse and sue less electricity in the construction process. It provides savings by conserving energy, water, fuel and other resources, and can directly reduce utility bills and operating costs of a project in the long term. Moreover, small and medium-sized companies may get a benefit from environmental procurement; it is also an opportunity for them to obtain the markets for their innovative solutions or products. Besides that, implementing green procurement can reduce prices for environmental technologies. Introducing green tendering criteria in the construction projects can affect the marketplace and develop new entrances for the businessman to the environmental field. Therefore, it has the potential for driving supply chain efficiency and increasing the market competition, innovation and capacity. In addition, implementing green saves money, especially when the new products use less energy, generate less waste and last longer. Although some products may be more expensive in terms of up-front acquisition cost, there will be more economic benefit over the products' whole lifecycles [17].

\subsection{Political Benefits}

Government plays important roles to promote and give awareness to the public sector to protect the environment. Based on the $10^{\text {th }}$ Malaysia Plan and Master Plan, the government had to develop a green building concept to preserve natural resources and increase urban life quality for the residents [18]. While private organizations perceive green procurement as a way to enhance the organizations' reputation of their social and environmental performance. This is because the organizations have eliminated the toxic substances from their products. It directly improves the relationship of cooperation among contractors and suppliers to create alternatives products. Therefore, it will increase the image in the eyes of the public towards the organizations. It will directly increase the level of customer satisfaction, and then as a key factor to maintain customer retention. Besides that, it will lead the contractor to the sustainable consumption of the resources. The government has a responsibility to give the perception to the citizens about the importance of green procurement in the construction 
project. For instance, the government can provide builder incentives; they are the main benefits of energy saving and worker productivity in developing sustainable green procurement in the construction industry. In short, a combination of legislation to enforce companies and the market to perform sustainable development and an incentive package for construction firms that practice sustainability in their projects is the best way that can be implemented by the government [18].

\section{Barriers towards green procurement in the construction industry}

\subsection{Lack of enforcement}

The government plays an indispensable role in promoting sustainability in construction. Sustainable construction can be perfectly implemented with the support of laws and regulations. Based on several types of research, there are many practitioners emphasizing that laws and legislation earmarked by the government are a key point to implementing green procurement in the construction industry. Although there have been several acts that focus on the environment, such as the Environmental Protection Act, Clean Air Act, Energy Policy Act etc, due to a lack of enforcement and monitoring they have been unsuccessful. Roman (2017) argued that implementation of green procurement can be considerably challenging, both in terms of technical aspects and navigating the organizational politics [19]. A lack of supportive legislative mandates or incentives at the local, state and national levels is a significant obstacle to promoting sustainable practices [20]. The government is responsible for taking into account sustainable development; nevertheless, there has been little support by providing finance and legal structure to incorporate environmental sustainability issues into the construction procurement [21]. For instance, the government can take action by devising new policies, giving incentives for people who are implementing green procurement or by the way of strong enforcement of the legislation.

\subsection{Lack of knowledge}

Green procurement is one of the complex processes. Many practitioners believe that developers have a lack of education and experience about the importance of green procurement in the construction industry or are unfamiliar with the concept of green procurement. Brammer and Walker stated that managers are unsure of how to incorporate sustainable issues in the procurement process [20]. A few practitioners argued that the concept of sustainable development has been misunderstood and there are various perceptions about it. Moreover, there is a low level of awareness and understanding about green procurement. This may be attributed to the lack of the training on sustainable development issues; the lack of a clear concept definition of sustainable construction and regulatory constraints; lack of information needed to make the right decisions related to the tissues, such as the selection of sustainable materials; lack of knowledge about what sustainable procurement is and how to accomplish it; and lack of information, knowledge, and competencies among procurers [22]. Besides that, they are lacking experience in the real world; it is a barrier for them to disseminate the theoretical into practice.

\subsection{Higher cost}


Financial constraints are primary barriers to sustainable procurement worldwide [22]. Cost issues are a prominent consideration for contractors and developers to implementing green procurement. Sustainability has often been perceived to be more expensive [19]. This is because the building approach and material selection are different from conventional building. However, it does not often have to have an extra cost [23]. The question is how to compare the costs between conventional buildings with green buildings? There is a need to set a baseline cost or cost model for all assessments to be alike. The additional or incremental cost of green building is always relative and relies on the eco-friendly features that are considered in the design stage. The additional cost would not be so high if the baseline design meets the specification as an eco-design up to a certain level, but it can be huge if green principles are not considered in the base design. Sustainable constructions are not famously implemented by developers and contractors due to them not gaining any advantages from it. Whilst the end user may obtain the benefits from sustainability, for instance, lower energy demand or the design that makes it easy to recycle after demolition [24]. A few practitioners have stated that sustainable construction is economically non-viable. Sustainable practices are believed to increase the initial expenditures of the project due to the higher initial upfront cost in terms of environmental oriented building design [25]. However, it should be noted that it is an adoption of a long-term perspective. Besides that, sustainability leads to less cost during the life time in the future, due to the easy reusability or recyclability which leads to a lower disposal cost.

\subsection{Passive culture}

Change resistance is a significant barrier to the adoption of green procurement. This change resistance results in a lack of demand by clients, and the stakeholder players in the construction project lead the influence of supply [26]. The demand and willingness of clients are the vital directions to the development of green procurement. Dobers and Wolff (2000) indicated that client awareness is a significant driver to lead the more sustainable practices [24]. Many people are always doing their work in same ways; it is difficult for them to change their mentality, especially the traditional construction methods practiced and building materials used with the higher respect by the people [26]. A few researchers believe that sustainability construction is an academic pursuit. It is often used on the intellectual side, but is rarely understood on the outside, leading to non-practice. Besides that, worldwide construction industries are lacking the corporate commitment to implement green procurement. The Sustainable Procurement Task Force reiterated that a lack of clear direction from top management to delivering sustainable development objectives through procurement process [27]. It is the responsibility of all levels of an organization, such as senior management and purchasing agents.

\subsection{Insufficient guidance and tools}

Many practitioners have stated that the Triple Bottom Line (TBL) parameter is one of the sustainable methods. The TBL is an accounting framework that consists of three performance dimensions, which are social, environmental and economic. Although there are TBL parameters already in place, there is a lack of proof on evaluating these tools in terms of credit point allocation for each of the triple bottom line parameters [22]. It is Papajohn et al. (2016) notion that there is no widely accepted method to identify the effectiveness of the existing tools in terms of evaluating the sustainability [28]. Currently, the existing tools and indicators are too broad and have no exactly usage or are to complicated to apply. Besides 
that, the definitions of many sustainability issues are confusing and vague, and sustainability is explained differently by different people [29]. In addition, Sourani \& Sohail (2011) mentioned that there is a lack of simple and structured guidance, demonstrations, and best practices to explain what is operationally meant by sustainability and how to carry it out [30]. Moreover, Williams et al. (2007) highlighted that scattered and complex procurement functions lead to unnecessary work for employees [31]. This may lead an organization to be overworked and under-resourced. In addition, a lack of training is one of the barriers for a subordinate to implement green procurement. Training is required that is concerned with the legal and technical aspects of green procurement, the concept of lifecycle costing and for end-users of the way to use the sustainable products.

\subsection{Lack of corporate commitments}

All organizational levels must have a commitment when implementing green procurement, not only from the top management but also the purchasing agents. Policy rules and regulations can help the corporate commitment in implementing green procurement. For example, ISO 20400 (sustainable procurement) is one of the guidelines for integrating sustainability into the procurement process of an organization. Some of the organizations are lacking in certain corporate processes, and their structures complicate the corporate ability to effectively address sustainability problems [32]. Therefore, clearly, green procurement policies aim to give awareness to the subordinates. It is guidance on social responsibility, which it complements by focusing specifically on the purchasing function. The final decision will be based on the responsibility of the top management level and how proactive they can promote green procurement. Figure 1 shows a break-up of potential challenges in achieving sustainable procurement in construction industry.

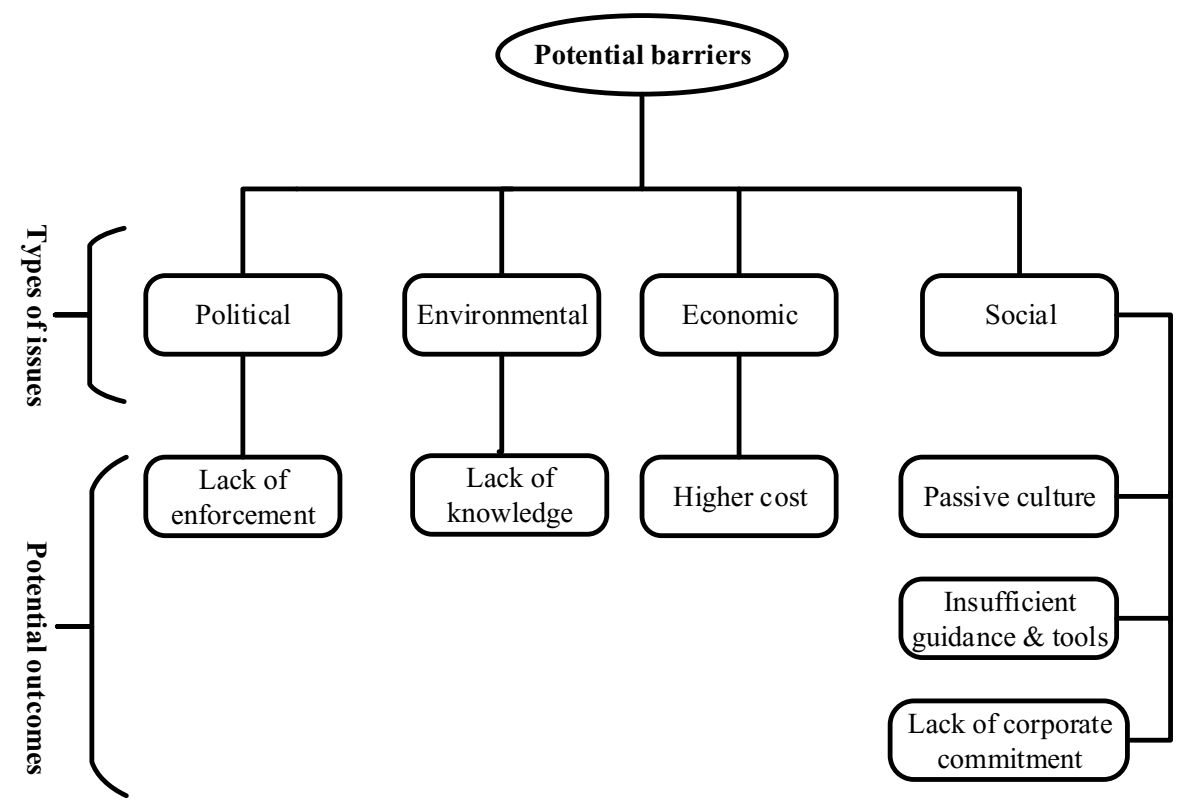

Fig. 1. Barriers towards green procurement.

\section{Conclusion}


This research has reviewed enablers and challenges towards green procurement in the construction industry and the benefits of implementing sustainability. Green procurement is a vital criterion in creating sustainability and plays a role in taking into account environmental criteria and standards to preserve the natural environment and resources by minimizing and reducing the negative impact of human activities. By implementing green procurement in the construction industry, it is also associated with the barriers for developing green procurement, such as lack of enforcement, higher cost, lack of awareness, passive culture and insufficient tools and indicators. Therefore, stakeholder players, such as government, purchasing agents, clients, architects and engineering consultants, contractors, and suppliers and quantity surveyors play significant roles in achieving sustainability in a construction project. With the cooperation of all the parties involved, the green procurement could be more efficient and increase the probability of success of a construction project.

The authors highly acknowledge Ministry of Higher Education Malaysia for Fundamental Research Grant Scheme (FRGS) under grant No. RDU170134 and Universiti Malaysia Pahang for their financial and technical support for completing this research work.

\section{References}

1. Dubrin. Growth opportunities for the global construction industry 2018-2023 - A Potential \$10.5 Trillion Market, Research and Markets (2018).

2. Green Tech Malaysia. Kementerian Tenaga Teknologi Hijau dan Air (KeTTHA). Malaysia Green Technology Master Plan: Driving economic and environmental benefits from green technology (2010).

3. United Nations General Assembly. Report of the world commission on environment and development: Our common future. Oslo, Norway: United Nations General Assembly, Development and International Co-operation: Environment. (1987).

4. The Chartered Institute of Building. A report exploring procurement in the construction industry. (2010).

5. R. Ruparathna, K. Hewage. Review of contemporary construction procurement practices. Journal of Management in Engineering, ASCE, 31(3) (2013).

6. P.E.D. Love, M. Skitmore, G. Earl. Selecting a suitable procurement method for a building project. Construction Management and Economics, 16(2), 221-233 (1998).

7. V. Albino, A. Balice, R. Dangelico. Environmental strategies and green product development: an overview on sustainability-driven companies. Recapturing the Corporate Environmental Management Research Agenda, 18, 83-96 (2009).

8. G. Ofori. Satisfying the customer by changing production patterns to realize sustainable construction. In Proceedings of the Joint Triennial Symposium of CIB Commissions W65 and W55, 1, 41-56. (1999).

9. M.A. Shelbourn, D.M. Bouchaghem, C.J. Anumba, P.M. Carillo, M.M . Khalfan, J. Glass. Managing knowledge in the context of sustainable construction. ITcon, 11, 57-71 (2006).

10. Research study on the current status and direction for green purchasing in Hong Kong. Green Council Hong Kong (2010).

11. S. Sayce, L. Ellison, P. Parnell. Understanding investment drivers for UK sustainable property. Building Research and Information. 35, 629 - 643 (2007).

12. United Nations Environment Programme (UNEP). Annual Report Seizing the Green Opportunity (2009). 
13. S.R. Vanakuru. Green building materials - The way towards sustainability. International Journal of Engineering Science and Computing, 6(10), 2649 - 2652) (2016)

14. Benefits from public procurement. The National Agency for Public Procurement (2015).

15. DMB Masonry Ltd. Eco-friendly construction (2017).

16. Capital E Analysis. Green building, redirecting our campus toward environmental sustainability (2011).

17. European Commission. Benefits of Green Public Procurement (GPP) - Environment (2016).

18. M. Samari, N. Ghodrati, R. Esmaeilifar, P. Olfat, \& M. W. M. Shafiei. The investigation of the barriers in developing green building in Malaysia. Modern Applied Science. 7 (2) (2013).

19. A. V. Roman. Institutionalizing sustainability: A structural equation model of sustainable procurement in US public agencies. Journal of Cleaner Production, 143, 1048-1059 (2017).

20. A. V. Roman. Institutionalizing sustainability: A structural equation model of sustainable procurement in US public agencies. Journal of Cleaner Production, 143, 1048-1059 (2017).

21. J. Ayarkwa, Ayirebi-Danso, P. Amoah. Barriers to implementation of ems in construction industry in Ghana, International Journal of Engineering Science, 2 (4), 37 45 (2010).

22. M. Laura, B. Pablo, S. Amalia, P. Eugenio. Sustainable public procurement: barriers and drawbacks. Sustainable Public Procurement 21th International Congress on Project Management and Engineering Cádiz (2017).

23. L. Preuss. Addressing sustainable development through public procurement: the case of local government. Supply Chain Management, 14 (3), 213. (2006).

24. R.J. Belfitt, S. Martion., S. Libby, H. Brian. Sustainable procurement - challenges for construction practice. Abstracts of Conference Papers: TSBE EngD Conference. (2011).

25. B. Sodagar, R. Fieldson. Towards a Sustainable Construction Practice. Construction Information Quarterly. $101-108$ (2008).

26. D. Susan, D. John, O. Eric. Barriers to Sustainable Construction in the Ghanaian Construction Industry: Consultants perspectives. Journal of Sustainable Development. 7 (1), $134-143$ (2014).

27. C. Felix, C. Lloyd. Barriers to sustainable procurement in Zimbabwe. Greener Journal of Business and Management Studies, 4(1), 014-018 (2014).

28. D. Papajohn, C. Brinker, M. E. Asmar. Uncovering key criteria to assess sustainability rating systems for the built environment. Construction Research Congress 2016: Old and New Construction Technologies Converge in Historic San Juan, ASCE, Reston, 13031312 (2016).

29. A. Sourani, M.Sohail. Enabling sustainable construction in UK public procurement. Proceedings of Institution of Civil Engineers: Management, Procurement and Law, 166(6), 297-312 (2013).

30. A. Sourani, M. Sohail. Barriers to addressing sustainable construction in public procurement strategies. Engineering Sustainability, 229-237 (2011).

31. S. Williams, T. Chambers, S. Hills, F. Dowson. Buying a better world: sustainable public procurement. (2007).

32. O. Nelly. Sustainable supply chain management implementation - enablers and barriers in the textile industry. Academic Open Access Publishing (MDPI) (2017).

33. O.A. Olubunmi, P.B. Xia, M. Skitmore. Green building incentives: a review. Renewable and Sustainable Energy Reviews, 59, 1611-1621 (2016).

34. N.Z. Abidin, A. Powmya. Drivers for green construction in Oman and its future prospects Middle-East. Journal of Scientific Research, 21, 929-935 (2014). 